\title{
Study on the Heat Generation Characteristics of Lithium Ion Power Battery with NCM/Si-C Composite Anode Material
}

\author{
Chuncheng $\mathrm{LIU}^{1}$, Jing Wang ${ }^{3 *}$, Yuefeng $\mathrm{SU}^{3}$, Shi \\ $\mathrm{CHEN}^{3}$, Feng WU ${ }^{3 *}$ \\ School of Materials Science \& Engineering \\ Beijing Institute of Technology \\ Beijing, China. \\ e-mail : wangjingbit98@bit.edu.cn, \\ wufeng863@bit.edu.cn
}

\author{
Shiqiang LIU ${ }^{2}$, Chunjing $\mathrm{LIN}^{4}$, Fang $\mathrm{WANG}^{5^{*}}$ \\ China Automobile Technology and Research Center \\ Tianjin, China \\ e-mail: Wangfang2011@ catarc.ac.cn
}

\begin{abstract}
Thermal characteristics of lithium ion batteries are particularly important for both the optimization of the battery cells and design of the thermal management system for battery packs. The Si-C composite applied in lithium ion battery could improve the battery's energy density. For a $3 \mathrm{Ah}$ pouch lithium ion battery with $\mathrm{NCM} / \mathrm{Si}$-C composite material system, the thermal characteristics were analyzed during the charging and discharging processes using the Extended Volume-Accelerating Rate Calorimeter. Meanwhile a 3 Ah pouch lithium ion battery with NCM/graphite composite material system was used as the reference sample. The internal resistance has great influence on the thermal behavior of Li-ion batteries. Thus, internal resistances of the battery cell were measured using the electrochemical impedance spectroscopy (EIS) method. Experimental results showed that the battery cell with NCM/Si-C generated much more amount of heat during charging and discharging processes. Temperature rise and heat generation power of the batteries increased as the current rate rising during charging and discharging processes. In addition, the overall internal resistance obtained by EIS had a close relationship with the heat generation behavior.
\end{abstract}

Keywords-lithium ion battery; Si-C composite; thermal characteristics; internal resistance; EIS

\section{INTRODUCTION}

Lithium ion batteries are widely applied in electric vehicles(EV), energy storage equipments and portable electronics with their favorable features of high energy density, high power density and long life etc., and have become a significant research topic[1][2][3]. During the processes of charging and discharging, lithium ion batteries generate large amount of heat due to the effects of ohm resistance, Li-ion migration and polarization phenomenon etc. For the lithium-ion cells with large capacities that are used in EVs, safe and long-time operations, that were affected by the ambient temperature and the internal temperature distribution inside the batteries[4], are necessary. With the development of electric vehicle, the development of high energy density battery is of the most urgent task. At present, graphite is the major anode material for lithium ion power battery. Silicon is the most promising alternative material as anode material in lithium-ion batteries to replace graphite for its higher gravimetric capacity, low average voltage and rational production cost [5][6].
In recent years, quantitative analysis on the thermal behavior of lithium-ion battery has been reported in several works. E. Schuster et al. [7] analyzed the thermal characteristics of a $40 \mathrm{Ah}$ pouch lithium-ion cell at different charging/discharging currents from $0.0125 \mathrm{C}$ to $1 \mathrm{C}$ under both isoperibolic and adiabatic conditions. Akram Eddahech et al.[8] focused on the thermal behavior of high-power lithium-ion cells during charge-discharge at several current rates and the influence of the state-of-charge variation and the impact of charge-discharge current rate on battery heat generation. Veth et al. [9] analyzed the thermal characteristics of a $50 \mathrm{Ah}$ large-format pouch lithium-ion cell under high current discharge conditions and the influence on the thermal behavior of lithium ion cells in charging and discharging process. Yoshiyasu Saito et al. [10] characterized the thermal behavior of 18650-type lithium-ion batteries which had degradation after long time storage during charging and discharging process using calorimetry. C. Lin et al. [11] studied the heat generation and energy efficiency of a prismatic $40 \mathrm{Ah} \mathrm{LiFePO} / \mathrm{C}$ battery and analyzed the influence of temperature on battery capacity during a mixed charge-discharge cycle. These works are basically based on battery cells with LFP or NCM/graphite material systems, and the thermal behavior of batteries with new material systems such as the NCM/Si-C should be studied. What's more, the battery internal resistance is the important factor that influence the heat generation in charging and discharging process. The ohmic and charge transfer resistances of the battery cell at different SOCs and temperatures could be studied using the electro-chemical impedance spectroscopy (EIS). Evaluations of the battery internal resistance by EIS are reported in the literature[12][13]. The thermal characteristics and internal resistance of large capacity lithium ion power batteries have always been concerned.

In this paper, the thermal characteristics of lithium ion battery cells were quantitatively analyzed during the charging and discharging processes using the Extended Volume-Accelerating Rate Calorimeter (EV+-ARC) in association with a battery electrochemical test system. A comparison of the thermal characteristics between the lithium ion battery with $\mathrm{NMC} / \mathrm{Si}-\mathrm{C}$ composite material system and $\mathrm{NMC/graphite} \mathrm{material} \mathrm{system} \mathrm{were} \mathrm{studied.} \mathrm{In}$ addition, EIS was applied to analyze the internal resistance 
of the battery cell at different state of charges (SOCs). Heat generation characteristic of the lithium ion cell were also compared with the obtained internal resistance. This work emphasized on the heat generation characteristics and the internal resistance of lithium ion batteries with $\mathrm{NMC} / \mathrm{Si}-\mathrm{C}$ composite material, which could be helpful for the optimization of high-energy power battery cells and the design of their thermal management systems.

\section{EXPERIMENT}

\section{A. Battery Cell}

A pouch power battery with $126 \mathrm{~mm}$ in length, $100 \mathrm{~mm}$ in width and $3 \mathrm{~mm}$ in height was selected for use in this study. The $\mathrm{Li}(\mathrm{Ni0} .5 \mathrm{Co} 0.3 \mathrm{Mn} 0.2) \mathrm{O} 2$ with layered structure was used as the cathode material. The anode material consisted of a Silicon/Carbon composite that contained $90 \mathrm{wt} \%$ of $\operatorname{SiOx}(\mathrm{x}$ approximately equal to 1 ), $5 \mathrm{wt} \%$ of graphite and $5 \mathrm{wt} \%$ of binder and conductive agent. The charging and discharging termination voltage were $4.35 \mathrm{~V}$ and $2.75 \mathrm{~V}$, respectively. And the capacity was $3 \mathrm{Ah}$ and the mass was $62 \mathrm{~g}$. The battery was named Battery $1 \#$ in this work for convenience. Battery 2\# was taken as a reference sample, in which the graphite was used as the anode material and the other materials are the same.

\section{B. Experimental Equipment}

The EV+-ARC produced by Thermal Hazard Technology (THT) wass used for the measuring of specific heat capacity and heat generation. During the test of the battery thermal behavior, Arbin battery test system and the EV+-ARC were coupled in utilization during charging and discharging processes. The German Zahner-zennium electrochemical workstation was applied in the EIS analysis. Specific environment with constant temperature and humidity was provided by the Giant Force chamber.

\section{Experimental Methods and Procedures}

1) Electrochemical-thermal analysis of the battery

To evaluate the thermal performance under adiabatic working conditions, the battery was charged at a rate of 0.5 $\mathrm{C}$ and discharged at rates of $0.5 \mathrm{C}, 1 \mathrm{C}$. The initial temperature of the battery cell and ARC chamber is $25 \pm 2{ }^{\circ} \mathrm{C}$. Charge of the Li-ion battery was performed in the constant current-constant voltage (CC-CV) mode and discharge of the battery was performed in the constant current mode in the $25 \pm 2^{\circ} \mathrm{C}$ environment. The heat generation quantity and instantaneous heat generation power could be calculated using the Equation (1) and Equation (2), respectively.

$$
\begin{aligned}
& Q=m C_{p} \Delta T \\
& P=m C_{p} \frac{d T}{d t}
\end{aligned}
$$

Where $\mathrm{Q}$ is the battery heat generation in $\mathrm{J}, \mathrm{m}$ is cell mass in $\mathrm{g}, \mathrm{C}_{\mathrm{p}}$ is the cell specific heat capacity in $\mathrm{J} /(\mathrm{g} \mathrm{K}), \Delta \mathrm{T}$ is cell temperature rise in $\mathrm{K}, \mathrm{P}$ is battery instantaneous heat generation power in $\mathrm{W}$, and $\mathrm{dT} / \mathrm{dt}$ is temperature rise rate in $\mathrm{K} / \mathrm{s}$.

\section{2) EIS test}

By measuring the cell open-circuit voltage over time when applied with current excitation, electrochemical impedance spectra EIS test could differentiate the ohmic internal resistance, charge transfer resistance, of a $\mathrm{Li}$-ion battery. The one-way scanning frequency of the smallamplitude sine wave was from $10 \mathrm{kHz}$ to $10 \mathrm{MHz}$.

\section{RESULTS AND DISCUSSION}

\section{A. Analysis of the Electrochemical Impedance Spectra}

The internal resistance of the Lithium ion battery was the key factor affecting the heat generation measured by EIS. The EIS technique is a method to analyze the internal resistance of battery. The Nyquist curve of Battery 1\# could be obtained by the EIS test as depicted in Figure 1.

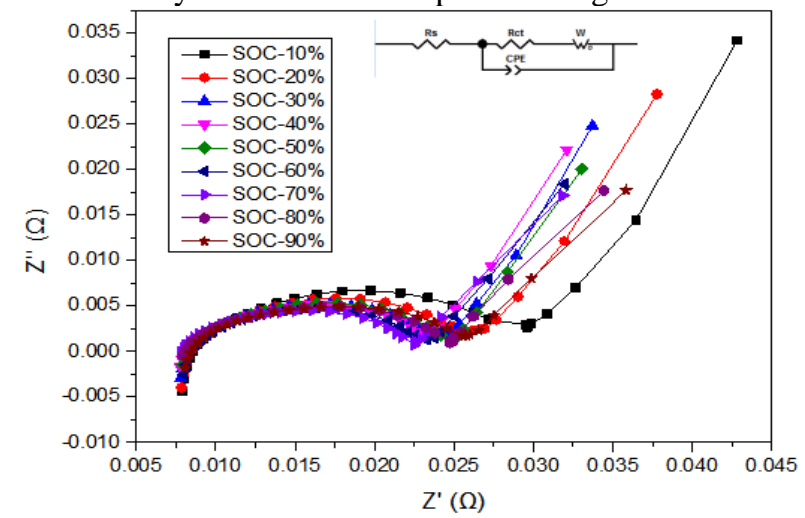

Figure 1. The Nyquist curve of the Li-ion battery cell at different SOCs of Battery 1\#.

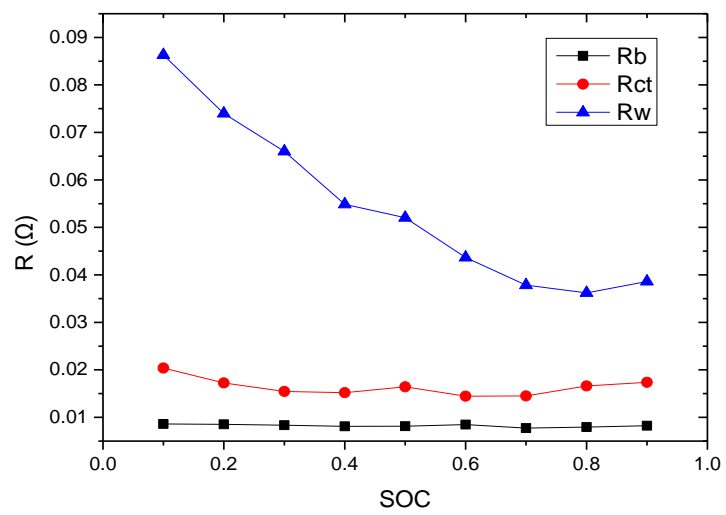

Figure 2. Nyquist Analysis of Battery 1\#.

It could be found that the Nyquist curves in the high frequency range showed no obvious changes with the SOC increasing from $10 \%$ to $90 \%$. The diameters of the semicircles varied at different SOC, and the maximum of diameters appeared at SOC $=10 \%$. The equivalent electric circuit (EEC) was identified in order to reproduce the internal electric effects of the battery. And the ohm internal resistance $\mathrm{Rb}$, the charge transfer resistance Rct and the diffusion resistance $\mathrm{Rw}$ could be analyzed by equivalent electric circuit, as shown in Figure 2. 
TABLE I. MEASUREMENT OF THE BATTERY HEAT GENERATION IN CHARGING PROCESS

\begin{tabular}{ccccc}
\hline Sample & Current Rate & $\begin{array}{c}\text { Terminal temperature } \\
\text { rise }\left({ }^{\circ} \mathrm{C}\right)\end{array}$ & Maximum Temperature Rise $\left({ }^{\circ} \mathrm{C}\right)$ & Average Heat Generation Power(W) \\
\hline Battery 1\# & $0.5 \mathrm{C}$ & 6.312 & 6.567 & 0.0843 \\
Battery 1\# & 1C & 15.029 & 15.469 & 0.3289 \\
Battery 2\# & $0.5 \mathrm{C}$ & 2.094 & 2.209 & 0.0294 \\
\hline
\end{tabular}

Performing fitting of the Nyquist curves in Figure 1, the ohmic resistance $\mathrm{Rb}$ and charge transfer internal resistance Rct of Battery 1\# at different SOCs were obtained, as shown in Fig. 2. It could be seen that the fluctuation and value of charge transfer resistance with SOC were obviously higher than that of ohmic resistance. The ohmic resistance $\mathrm{Rb}$, which is about $8.24 \mathrm{~m} \Omega$, appeared almost constant when SOC increasing from $10 \%$ to $90 \%$. The charge transfer resistance Rct was relatively larger in high and low SOC section, that is much larger at $\mathrm{SOC}=10 \%$. And the diffusion resistance Rw decreased with the increase of SOC with a greater change.

\section{B. Electrochemical Calorimetric Analysis of Li-ion battery}

Battery 2\# served as a reference sample for the electrochemical thermal analysis of Battery $1 \#$.

\section{1) Specific heat capacity}

The specific heat capacity is essential to calculate the heat generated of the battery. According to the literature [7], the specific heat capacity of a Li-ion battery was measured by using an ARC. The temperature data, mass and heating power were recorded in the test. The specific heat capacity of Battery 1\# and Battery 2\# were calculated from the Equation (3) to be $1.48 \mathrm{~J} \cdot \mathrm{kg}-1 \cdot \mathrm{K}-1,1.59 \mathrm{~J} \cdot \mathrm{kg}-1 \cdot \mathrm{K}-1$, respectively.

$$
\mathrm{Cp}=\frac{\mathrm{Pt}}{m\left(\mathrm{~T}_{2}-\mathrm{T}_{1}\right)}
$$

Where $\mathrm{Cp}$ is the specific heat capacity of a Li-ion battery, $\mathrm{P}$ is the heating power, $\mathrm{t}$ is the heating time, $\mathrm{m}$ is the mass of battery, and $\mathrm{T} 1$ and $\mathrm{T} 2$ are initial temperature and termination temperature of the battery in the test.

\section{2) Thermal characteristics of Li-ion cell}

a) Charging process

The temperature rise and average heat generation power of the Li-ion battery cell during the charging processes were shown in Table 1. The terminal temperature rise was $6.312{ }^{\circ} \mathrm{C}, 15.029{ }^{\circ} \mathrm{C}$ and $2.094{ }^{\circ} \mathrm{C}$ of Battery $1 \#-0.5 \mathrm{C}$, Battery $1 \#-1 \mathrm{C}$ and Battery $2 \#-0.5 \mathrm{C}$, respectively. The average temperature rise rates were $0.055^{\circ} \mathrm{C} / \mathrm{min}, 0.215{ }^{\circ} \mathrm{C} / \mathrm{min}$ and $0.017{ }^{\circ} \mathrm{C} / \mathrm{min}$, respectively. It can be observed that the heat generation and power of Battery 1\# were much higher than Battery 2\# during $0.5 \mathrm{C}$ charging processes. When the current was $1 \mathrm{C}$, the temperature rise increased as the charging current rate rising.

The heat generation power and current as a function of time during charging processes were shown in Figure. 3. It could be seen that the temperature rise rates of Battery 1\# increased obviously when the charge current rate rose from $0.5 \mathrm{C}$ to $1 \mathrm{C}$-rate, the temperature rise rates of Battery $2 \#$ was lower than Battery $1 \#$ in $0.5 \mathrm{C}$ current rate in charging process. After that, the heat generation power decreased gradually with the charging in process. In the constant current charging period, the heat generation power fluctuated over time that was a little bit lower in the later period. During the constant voltage charging stage, the heat production power gradually reduced as current gradually dropping to $0.6 \mathrm{~A}$, and the temperature could be a little bit lower.
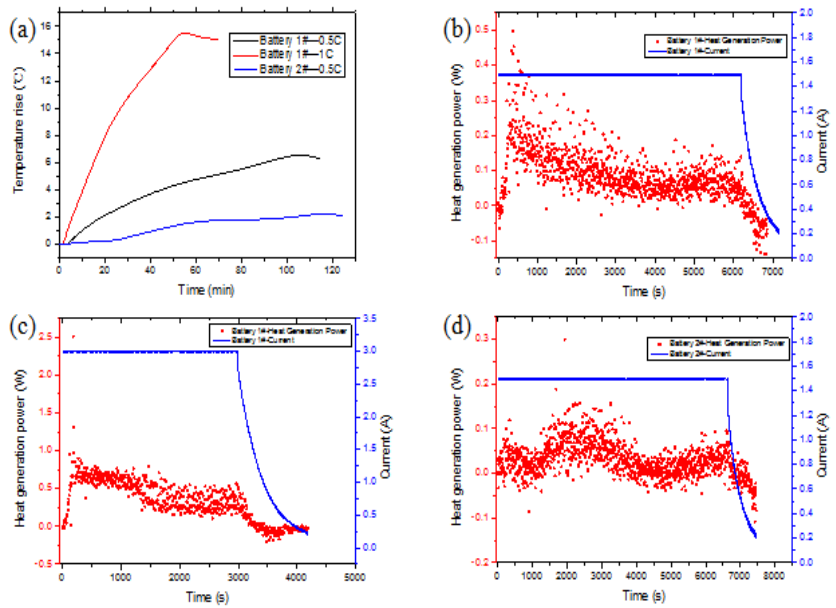

Figure 3. The temperature rise, heat generation power and current as a function of time during charging processes (a) Temperature rise (b) Battery $1 \#-0.5 \mathrm{C}$ charging current rate (c) Battery $1 \#-1 \mathrm{C}$ charging current rate (d) Battery 2\# $-0.5 \mathrm{C}$ charging current rate.

\section{b) Discharging process}

The total temperature rise and the average heat generation power of the battery cell during the discharging process were shown in Table 2 and Figure 4 . It could be seen that, the temperature rise and the heat generation power of Battery $1 \#$ were much higher than Battery $2 \#$ in $0.5 \mathrm{C}$ and $1 \mathrm{C}$-rate discharging processes. In discharging process, the average temperature rise rates of Battery $1 \#-0.5 \mathrm{C}$.Battery $1 \#-1 \mathrm{C}$ and Battery $2 \#-0.5 \mathrm{C}$ Battery $2 \#-1 \mathrm{C}$ were $0.076^{\circ} \mathrm{C} / \mathrm{min}$, $0.316^{\circ} \mathrm{C} / \mathrm{min}$ and $0.032^{\circ} \mathrm{C} / \mathrm{min}, 0.152^{\circ} \mathrm{C} / \mathrm{min}$, respectively. The average temperature rise rates of the cell during discharging process increased significantly with current rate rising. The heat generation powers of Battery $2 \#-0.5 \mathrm{C}$ were small during the majority of discharging time. It could be observed in Figure 4(b), that the heat generation power of the batteries increased obviously both in magnitude and fluctuation as the discharge rises. The heat generation power varied in a similar way in different current rate. Also, in the final stage of the discharge, heat generation power was increasing significantly. In addition, the heat generation powers of the cell were relatively higher during the initial and final periods, and relatively lower during the middle stage. 
TABLE II. MEASUREMENT OF THE BATTERY HEAT GENERATION IN DISCHARGING PROCESS

\begin{tabular}{cccc}
\hline Sample & Current Rate & Terminal temperature rise $\left({ }^{\circ} \mathrm{C}\right)$ & Average Heat Generation Power(W) \\
\hline Battery 1\# & $0.5 \mathrm{C}$ & 8.484 & 0.1156 \\
Battery 1\# & 1C & 17.531 & 0.4815 \\
Battery 2\# & $0.5 \mathrm{C}$ & 3.881 & 0.0565 \\
Battery 2\# & 1C & 8.839 & 0.2653 \\
\hline
\end{tabular}
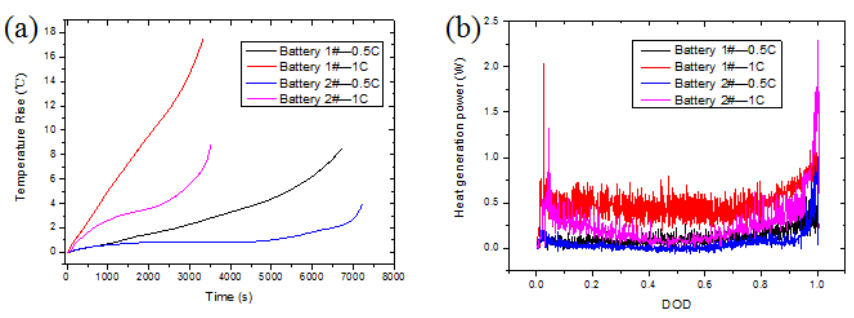

Figure 4. The thermal behavior of Battery 1\# and Battery 2\# during discharging process, (a)temperature rise as functions of time (b)the instantaneous heat generation power as functions of DOD.

The heat generation power and voltage as a function of time during charging processes at different current rates were shown in Figure 5. For these discharge cases, the battery was discharged at a certain current rate to the same cutoff voltage of $2.75 \mathrm{~V}$. The voltage was dropping during discharging process. And for Battery 1\#, the trend of voltage dropping was relatively stable. The voltage of Battery $2 \#$ dropped more rapidly in the later discharging period. In the initial and final stage of the discharge, the heat generation power increased quickly when the voltage dropped rapidly on the account of charge transfer internal resistance. The variation trend of heat generation power and voltage was relatively stable in the middle of the discharge process.
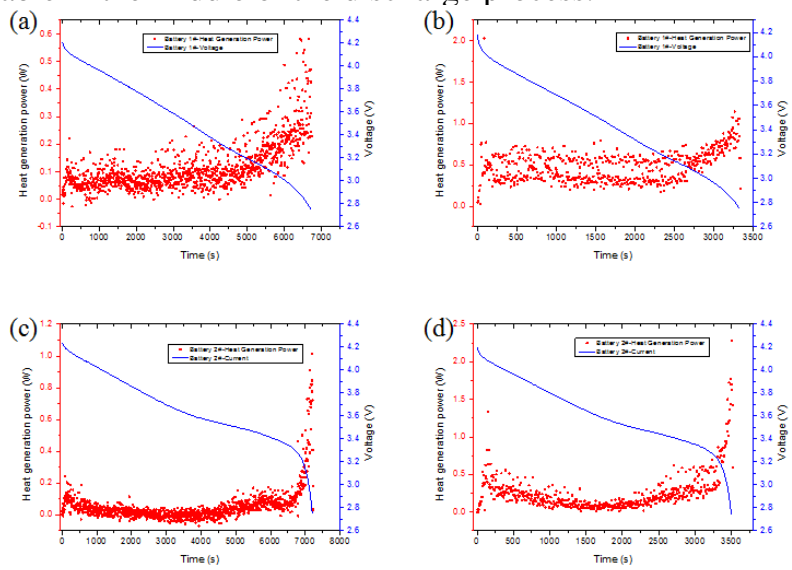

Figure 5. The heat generation power and voltage as a function of time during discharging processes (a)Batter $1 \#-0.5 \mathrm{C}$ discharging current rate (b)Batter 1\#-1C discharging current rate(c) Batter 2\#-0.5C discharging current rate(d) Battery 2\#-1C discharging current rate.

To further investigate the relationship between the internal resistance and the heat generation, the internal resistance calculated by heat generation powers obtained by the ARC test of Battery 1\# were compared with the ones measured by the EIS test in Figure 6. It can be observed that the internal resistance obtained from these two methods were well fitted in trend. And the result from EIS was a little bit larger. The influence of the heat characteristics deserves further study, during battery discharging process from the irreversible ohmic heat, and the reversible reaction heat and the side reaction heat.

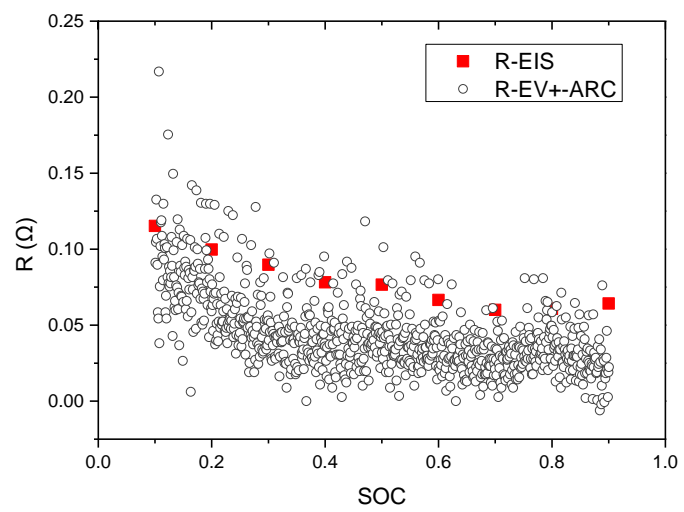

Figure 6. The internal resistance obtained by the ARC test results in Battery $1 \#$ 0.5C-rate discharging process and total internal resistance from the EIS test.

\section{CONCLUSION}

In this paper, the internal resistance was analyzed by the electrochemical impedance spectroscopy (EIS). The numerical and variation amplitude shows: $\mathrm{Rb}<\mathrm{Rct}<\mathrm{Rw}$. The behavior of the heat generation between the lithium ion battery with different anode material during both charging and discharging processes were conducted. The temperature rise and heat generation power of the batteries increased as current rate rising in charging and discharging process. And the heat generation power curve shows symmetrical Ushaped characteristic during discharging processes. The lithium ion power battery with $\mathrm{NCM} / \mathrm{Si}$-C composite material could generated more amount of heat in charging and discharging process in comparison to that with $\mathrm{NCM} /$ graphite material. In charging process, the heat generation power became lower when the current dropped in the constant voltage stage. In the final stage of discharging process, the heat generation power rose as the voltage dropping. The heat generation power was relatively stable in the middle stage of charging and discharging process. What's more, the internal resistances calculated by the ARC measured were close to the EIS test results. Thus, the EIS test could provide some reasonable results for the estimation of the battery heat generation power.

\section{ACKNOWLEDGMENT}

This work was financially supported by the National Key R\&D Program of China for New Energy Vehicle (2016YFB0100400) and the Special fund of Beijing Coconstruction Project. 


\section{REFERENCES}

[1] Choi N S, Chen Z, Freunberger S A,S. A. Freunberger et al."Challenges facing lithium batteries and electrical double-layer capacitors". Angewandte Chemie International Edition, vol.51,Sept 2012, PP:9994-10024,doi: 10.1002/anie.201201429.

[2] Liu J. "Addressing the Grand Challenges in Energy Storage". Advanced Functional Materials,vol.23,Feb 2013, PP:924928,doi:10.1002/adfm.201203058.

[3] Sanfélix, J., Messagie, M., Omar, N., Mierlo, J. V., and Hennige, V. "Environmental performance of advanced hybrid energy storage systems for electric vehicle applications". Applied Energy, vol.137, Jul.2015, pp:925-930,doi:10.1016/j.apenergy.2014.07.012.

[4] Bandhauer T M, Garimella S, Fuller T F. "A Critical Review of Thermal Issues in Lithium-Ion Batteries". Journal of the Electrochemical Society, vol.158,Jan 2011, PP:R1-R25.doi: 10.1149/1.3515880.

[5] Fei Luo, Bonan Liu, Jieyun Zheng, Geng Chu, Kaifu Zhong and Hong $\mathrm{Li}$ et al. "Review-Nano-silicon/carbon composite anode materials towards practical application for next generation Li-ion batteries". Journal of the Electrochemical Society, vol.162, Oct 2015, PP: A2509-A2528,doi: 10.1149/2.0131514jes.

[6] Nitta N and Yushin G. "High-Capacity Anode Materials for LithiumIon Batteries: Choice of Elements and Structures for Active Particles". Particle \& Particle Systems Characterization,vol.13, 2014, pp:317336.dol: 10.1002/ppsc.201300231Schuster E, Ziebert C, Melcher A and HJ Seifert. "Thermal behavior and electrochemical heat generation in acommercial 40Ah lithium ion pouch cell". Journal of Power Sources, vol:286, Mar.2015, PP:580589.doi:10.1016/j.jpowsour.2015.03.170.
[7] Schuster E, Ziebert C, Melcher A and HJ Seifert. "Thermal behavior and electrochemical heat generation in acommercial 40Ah lithium ion pouch cell". Journal of Power Sources, vol:286,Mar.2015, PP:580589.doi:10.1016/j.jpowsour.2015.03.170.

[8] Eddahech A, Briat $\mathrm{O}$ and Vinassa J M. "Thermal characterization of a high-power lithium-ion battery: Potentiometric and calorimetric measurement of entropy changes". Energy, vol.61,Oct.2013, pp:432439, doi:10.1016/j.energy.2013.09.028.

[9] Veth C, Dragicevic D, Merten C. "Thermal characterizations of a large-format lithium ion cell focused on high current discharges". Journal of Power Sources, vol.267,Jun.2014, pp:760769,doi:10.1016/j.jpowsour.2014.05.139.

[10] Saito Y, Shikano M and Kobayashi H."Heat generation behavior during charging and discharging of lithium-ion batteries after longtime storage". Journal of Power Sources, vol.244,Dec.2013, pp:294299,doi:10.1016/j.jpowsour.2012.12.124.

[11] Lin C., Xu S,Li Z,Li B,Chang G and Liu, J. "Thermal analysis of large-capacity LiFePO 4, power batteries for electric vehicles". Journal of Power Sources, vol.294,Jul.2015, pp:633642,doi:10.1016/j.jpowsour.2015.06.129.

[12] Vertiz G, Oyarbide M, Macicior H, et al. "Thermal characterization of large size lithium-ion pouch cell based on 1d electro-thermal model". Journal of Power Sources, vol.272,Sept.2014,PP:476484,doi:10.1016/j.jpowsour.2014.08.092.

[13] Shrestha B, Novak P, Wetz D, A Matassol. "Evaluation of High C Rate Cycle Induced Aging on Low Impedance Lithium-Ion Batteries Using In-Situ Electrochemical Impedance Spectroscopy (EIS) Analysis". Ecs Transactions,vol.58,Nov. 2013,pp: 207-222,doi: $10.1149 / 05848.0207$ ecst. 